\title{
Diet-related variation in cellular retinol-binding protein type II gene expression in rat jejunum
}

\author{
Kazuhito Suruga ${ }^{1}$, Masaaki Kitagawa ${ }^{1}$, Hiromitsu Yasutake ${ }^{1}$, Sachiko Takase ${ }^{2}$ and Toshinao Goda ${ }^{1}$ * \\ ${ }^{1}$ Laboratory of Nutritional Physiology and COE Program in the 21st century, University of Shizuoka School of Food and Nutritional \\ Sciences, Shizuoka 422-8526, Japan \\ ${ }^{2}$ Department of Nutrition, Siebold University of Nagasaki, Nagasaki 851-1200, Japan
}

(Received 23 December 2004 - Revised 17 June 2005 - Accepted 12 July 2005)

\begin{abstract}
Cellular retinol-binding protein type II (CRBPII) is involved in the transport of vitamin A and its metabolism in the small intestine. In the present study, we demonstrated diet-related variations in CRBPII expression in rat jejunum. The CRBPII protein and mRNA levels increased in parallel after the start of feeding period regardless of whether the feeding period was restricted to the hours of darkness or of light. In addition, this variation was observed in the rats fed high-fat diet or low-fat diets, but not in those fed a fat-free diet or in fasted rats. A similar diet-induced variation was seen in the mRNA of liver-type fatty acid-binding protein in rat jejunum. In the transient transfection experiment, unsaturated fatty acid increased rat CRBPII gene promoter activity via the PPAR $\alpha$ /retinoid X receptor- $\alpha$ heterodimer. Taken together, these results suggest that the diet-related variation in CRBPII expression in rat jejunum may be brought about by the transcriptional induction of CRBPII gene expression mainly triggered by dietary fatty acids.
\end{abstract}

CRBPII: L-FABP: small intestine: PPAR: dietary fat

It is well known that the capability to digest and absorb carbohydrates and proteins in the small intestine exhibits diurnal variations in the rat (Furuya et al. 1979). A number of reports have focused on the diurnal variations in carbohydrate-related proteins, including hexose transporters (Castello et al. 1995; Corpe \& Burant, 1996) and disaccharidases (Saito et al. 1975, 1976). Although the precise mechanisms responsible for these diurnal variations are still unclear, it is evident that the rhythmic variations of these carbohydrate-related proteins are strictly dependent on feeding behaviour. Moreover, the expression of these carbohydraterelated proteins is also rapidly regulated by some dietary factors (Goda \& Koldovsky, 1988; Kishi et al. 1999). Thus, carbohydrate-related proteins may be regulated by both diurnal rhythm and dietary factors. Little attention has, however, been given to the possible diurnal variations of digestive and absorptive capability for nutrients including fat and fat-soluble vitamins.

Cellular retinol-binding protein type II (CRBPII) is an abundant cytosolic protein found in the small intestinal enterocytes of many vertebrates (Ong, 1984; Ong \& Page, 1987; Goda \& Takase, 1989). CRBPII specifically binds retinol or retinal and may play an important role in the intestinal transport of vitamin $\mathrm{A}$ and its metabolism. Indeed, CRBPII-retinal and CRBPII-retinol complexes serve as substrates for the conversion of retinal into retinol, catalysed by retinal reductase (Kakkad \& Ong, 1988), and for the conversion of retinol into retinyl esters, catalysed by lecithin:retinol acyltransferase (Ong et al. 1987). Thus, the alteration in CRBPII level in the small intestine may lead to changes in its capacity to absorb and transport vitamin A.
We and others have previously reported that intestinal CRBPII gene expression is altered in various physiological conditions: the level of CRBPII mRNA is, for example, abruptly elevated during the perinatal period in rats (Levin et al. 1987) and chicks (Suruga et al. 1997), and CRBPII gene expression can be induced by dietary fatty acids (Goda et al. 1994; Suruga et al. 1995; Takase et al. 1998). In the present study, we investigated whether diurnal variation or food consumption contributed to the expression of CRBPII in rat jejunum. We demonstrated that the variation in expression level of CRBPII in rat jejunum during the course of a day was triggered especially by the consumption of dietary fat but not by the diurnal rhythm of feeding.

\section{Materials and methods \\ Animals and experimental diets}

Three studies on variation in CRBPII gene expression were conducted. All the animals used in this study were 6-week-old male Wistar rats. All the rats were housed under a light cycle with $12 \mathrm{~h}$ darkness from $18.00 \mathrm{~h}$ to $06.00 \mathrm{~h}$. The rats were killed by decapitation every 4 or $6 \mathrm{~h}$ as indicated.

In the first study, to investigate the diurnal pattern of jejunal CRBPII expression, the rats were separated into two groups; one group of animals were fed a standard laboratory chow diet (MF; Oriental Yeast Co., Tokyo, Japan) only during the dark period (from $18.00 \mathrm{~h}$ to $06.00 \mathrm{~h}$ ) for 1 week. The other group of 
animals received the same diet during the $6 \mathrm{~h}$ period between $09.00 \mathrm{~h}$ and $15.00 \mathrm{~h}$ (a part of the light period) for 2 weeks.

In the second study, to investigate the effects of dietary fat on the variation in jejunal CRBPII gene expression, three types of diet containing different amounts of fat (Table 1) were given to three groups of rats. The first group of rats received access to a synthetic low-fat diet containing $2.4 \%(\mathrm{w} / \mathrm{w})$ corn oil only during the $6 \mathrm{~h}$ period between $09.00 \mathrm{~h}$ and $15.00 \mathrm{~h}$ for 2 weeks. The second group received access to a synthetic low-fat diet only during the $6 \mathrm{~h}$ period between $09.00 \mathrm{~h}$ and $15.00 \mathrm{~h}$ for $13 \mathrm{~d}$ and then received a synthetic fat-free diet only during the $6 \mathrm{~h}$ period between $09.00 \mathrm{~h}$ and $15.00 \mathrm{~h}$ on the fourteenth day. The third group was fed a high-fat diet containing $24 \%(\mathrm{w} / \mathrm{w})$ corn oil during the same $6 \mathrm{~h}$ period for 2 weeks.

In the third study, rats received access to a synthetic low-fat diet only during the $6 \mathrm{~h}$ period between $09.00 \mathrm{~h}$ and $15.00 \mathrm{~h}$ for $13 \mathrm{~d}$ and were then fasted during $6 \mathrm{~h}$ period only on the fourteenth day. The experimental procedures used in the present study met the guidelines of the animal usage committee of the University of Shizuoka.

\section{Preparation of intestinal samples}

The entire small intestine was removed, and the duodenum extending from the pylorus to the ligament of Treitz was discarded. The jejuno-ileum was divided into three segments of equal length. The proximal two-thirds (jejunum) of the jejuno-ileum were flushed with ice-cold $0.9 \% \mathrm{NaCl}$ solution. A $1.5 \mathrm{~cm}$ segment $(100 \mathrm{mg}$ ) was excised from the middle region of the jejunal segment and immediately used for total RNA extraction. An adjacent $20 \mathrm{~cm}$ segment was saved at $-20^{\circ} \mathrm{C}$ for measurement of CRBPII content.

\section{Quantification of jejunal CRBPII content}

Mucosa was scraped from the jejunal segment with a glass microscope slide and homogenised in four volumes of ice-cold $0 \cdot 2 \mathrm{M}-\mathrm{K}_{2} \mathrm{PO}_{4}$ buffer $(\mathrm{pH}$ 7.2). Following centrifugation at $10000 \mathrm{~g}$ for $60 \mathrm{~min}$ at $4 \%$, the cytosolic fraction was used for the measurement of CRBPII. Quantification of the jejunal CRBPII content was performed by sandwich-type ELISA using monospecific anti-rat CRBPII IgG as previously described (Takase et al. 1993).

\section{RNA analysis}

Total RNA was extracted from rat jejunum by the acidified guanidine thiocyanate method (Chomczynski \& Sacchi, 1987).

Table 1. Composition of the experimental diets

\begin{tabular}{lccr}
\hline Dietary components & $\begin{array}{c}\text { Fat-free } \\
\text { (g/kg diet) }\end{array}$ & $\begin{array}{c}\text { Low-fat } \\
\text { (g/kg diet) }\end{array}$ & $\begin{array}{r}\text { High-fat } \\
\text { (g/kg diet })\end{array}$ \\
\hline Vitamin-free casein & 157.0 & 157.0 & 159.0 \\
$\beta$-corn starch & 580.0 & 526.0 & 36.0 \\
Corn oil & - & 24.0 & 247.0 \\
Mineral mix, AIN-76 & 28.0 & 28.0 & 28.0 \\
Vitamin mix, AIN-76 & 8.0 & 8.0 & 8.0 \\
DL-Methionine & 2.4 & 2.4 & 2.4 \\
Choline bitartrate & 1.6 & 1.6 & 1.6 \\
2\% Agar solution & 223.0 & 253.0 & 518.0 \\
\hline
\end{tabular}

Northern blot analysis was performed using ${ }^{32} \mathrm{P}$-labelled cDNA probes as previously described (Goda et al. 1994). The cDNA probes used in the Northern blot analysis were as follows: rat CRBPII cDNA (Goda et al. 1994), rat liver fatty acid-binding protein (L-FABP) cDNA (Suruga et al. 1999) and rat 28S ribosomal RNA (Suruga et al. 1999). For quantification of specific mRNA signals in the Northern blots, the density of radioactivity was scanned using a bio-image analyser (BAS 2000; Fujifilm, Tokyo, Japan), and the signals were normalised using the corresponding 28S rRNA level.

\section{Plasmid construction, cell culture and transient transfection}

Expression vectors for the mouse PPAR $\alpha$ (pCMX-PPAR $\alpha$ ) and retinoid X receptor- $\alpha(\mathrm{RXR} \alpha$; $\mathrm{pCMX}-\mathrm{RXR} \alpha)$ were generously provided from Dr RM Evans. Two types of rat CRBPII gene luciferase reporter vector were constructed as follows. First, the promoter region of the rat CRBPII gene (GenBank accession number M16400; 237-1037) was ligated into the PGV-B2 basic vector (TOYO Ink Co., Tokyo, Japan), and two tandem repeats of the RE3 region of the rat CRBPII gene (Suruga et al. 1999) were ligated into the PGV-P promoter vector (TOYO Ink Co.). These were designated prCRBPII pro-LUC and prCRBPII(RE3)2SV40-LUC, respectively.

CV-1 cells were purchased from American Type Culture Collection (Rockville, MD, USA) and cultured at $37^{\circ} \mathrm{C}$ in a humidified atmosphere $\left(5 \% \mathrm{CO}_{2}, 95 \%\right.$ air $)$ in Dulbecco's modified eagle's medium (Sigma, St Louis, MO, USA) supplemented with $10 \%$ (v/v) fetal calf serum (Biological Industries, Kibbutz Bet-Haemek, Israel), 2 mm-glutamine (Sigma, St Louis, MO, USA), $20 \mathrm{~mm}-\mathrm{HEPES}$ and $1 \%(\mathrm{v} / \mathrm{v})$ antibiotic-antimycotic mixed solution (Nacalai Tesque, Kyoto, Japan). For the transfection, cells were plated at a density of $3.0 \times 10^{4}$ cells per well in a ninety-six-well cell culture plate (Iwaki glass, Tokyo, Japan). Twenty-four hours after plating, the culture medium was removed and the cells washed once with Opti-MEM (Invitrogen, Tokyo, Japan).

Transfection was performed using Tfx-10 reagent (Promega Corporation, Madison, WI, USA) according to the manufacturer's instructions. Briefly, each well was transfected with $100 \mathrm{ng}$ constructed luciferase reporter vector, $50 \mathrm{ng}$ each of $\mathrm{pCMX}-\mathrm{RXR} \alpha$ and $\mathrm{pCMX}$-PPAR $\alpha$ expression vectors (or $100 \mathrm{ng}$ pCMX mock vector) and $2 \mathrm{ng}$ Renilla luciferase control vector phRG-TK (Promega Corporation), which were complexed with $0.6 \mu 1 \mathrm{Tfx}-$ 10 reagent in $50 \mu \mathrm{l}$ Opti-MEM. One hour after transfection, the DNA-Tfx-10 complex was removed and cells were incubated for $48 \mathrm{~h}$ in a serum-free culture medium containing $2 \mathrm{mg} / \mathrm{ml}$ bovine serum albumin (BSA) with or without $100 \mu \mathrm{M}$ fatty acids. Luciferase activity was determined by the dual-luciferase reporter assay system (Promega Corporation) and expressed as fold-activation relative to control (pCMX mock vector only, no fatty acids).

\section{Statistical analysis}

All results were subjected to one-way ANOVA. Differences in mean values between groups were tested using Ryan's multiple range test, or differences in mean values between the two groups were analysed by Student's $t$ test (Stat-Light, Yukmus Co., Tokyo, Japan). Both differences were considered statistically significantly different at $P<0 \cdot 05$. 


\section{Results}

Feeding-related variation in jejunal CRBPII protein and mRNA levels

When rats were fed a standard laboratory diet during the dark period $(18.00 \mathrm{~h}$ to $06.00 \mathrm{~h})$, both CRBPII protein and mRNA levels were elevated during the feeding period; the lowest levels were seen at $16.00 \mathrm{~h}$, and both levels gradually increased during the dark period (Fig. 1(A)). To examine whether these variations in CRBPII expression were related to the feeding period or were synchronised to the light-dark cycle, the feeding period was shifted to the time between $09.00 \mathrm{~h}$ and $15.00 \mathrm{~h}$ (i.e. the light period). As a result, the pattern of variation in jejunal CRBPII mRNA levels shifted, and remarkable increases in CRBPII mRNA levels were observed after the start of the feeding period in spite of the light (Fig. 1(B)).
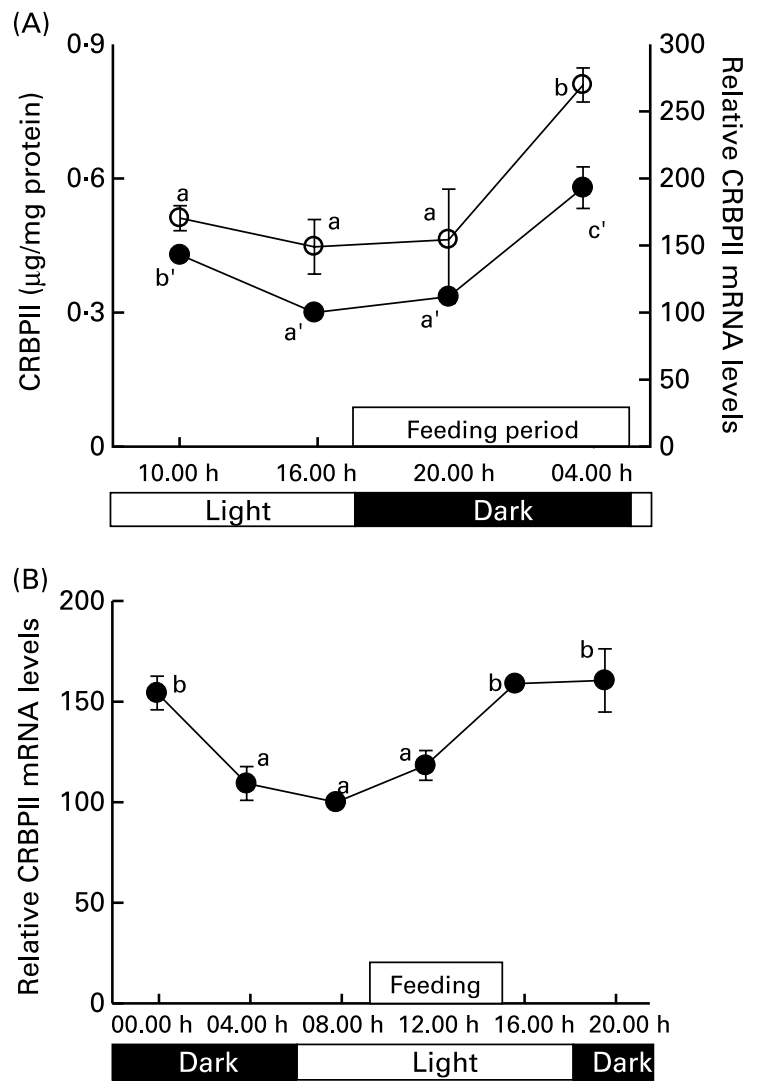

Fig. 1. Diet-related variation in cellular retinol-binding protein (CRBP) II protein and CRBPII mRNA levels in rat jejunum. (A) Rats had access to a standard laboratory diet only during the dark period $(18.00 \mathrm{~h}$ to $06.00 \mathrm{~h}$ ) for 1 week and were killed by decapitation at $6 \mathrm{~h}$ intervals. Total RNA was isolated from the jejunum, and the CRBPII mRNA levels $(\bullet)$ were quantified by Northern blot hybridisation using $28 \mathrm{~S}$ rRNA signals for normalisation. Jejunal cytosolic CRBPII protein (O) was quantified by ELISA and expressed as $\mu \mathrm{g} / \mathrm{mg}$ jejunal mucosal protein. (B) Rats were fed a standard laboratory diet only during the time indicated during the light hours (from $09.00 \mathrm{~h}$ to $15.00 \mathrm{~h}$ ) for 2 weeks and were killed by decapitation at $4 \mathrm{~h}$ intervals. Total RNA was isolated from the jejunum, and the CRBPII mRNA levels were quantified by Northern blot hybridisation using 28S rRNA signals for normalisation. Values represent means with their standard errors for three rats for each time point. $\mathrm{a}, \mathrm{b}, \mathrm{c}$ Values with unlike superscript letters on the same curve are significantly different at $P<0.05$ by Ryan's multiple range test.
Dietary fat-induced variation in jejunal CRBPII and L-FABP mRNA levels

We previously reported that dietary fat, especially unsaturated fatty acids, enhanced CRBPII mRNA levels in rat jejunum (Goda et al. 1994; Suruga et al. 1995; Takase et al. 1998). Therefore, we next investigated whether dietary fat affected the variation in jejunal CRBPII mRNA level. Rats were meal-fed either an isoenergic low-fat or high-fat diet during the $6 \mathrm{~h}$ period (from $09.00 \mathrm{~h}$ to $15.00 \mathrm{~h}$ ) each day for 2 weeks. In both dietary groups, CRBPII mRNA levels were similarly increased after the start of feeding (Fig. 2). Overall mRNA levels were higher in the animals fed the high-fat diet than in animals fed the low-fat diet at all times investigated over the $24 \mathrm{~h}$ period (Fig. 2). CRBPII mRNA levels were significantly higher $(P<0.05)$ at $20.00 \mathrm{~h}$ than at $08.00 \mathrm{~h}$ in both dietary groups $(2 \cdot 9$-fold in animals fed the low-fat diet and 2.3-fold in those fed the high-fat diet). However, no increase in CRBPII mRNA level after the start of feeding was seen in the rats fed a fat-free diet on the last day (Fig. 2). In addition, when the rats were fasted on the last day, CRBPII mRNA levels did not change between $08.00 \mathrm{~h}$ and $20.00 \mathrm{~h}$ (Fig. 2). L-FABP, which is considered to be involved in intestinal and liver fatty acid transport, showed a similar variation in mRNA level in rat jejunum to that of CRBPII (Fig. 2). The animals fed the high-fat diet also exhibited greater L-FABP, as well as CRBPII, mRNA levels than those fed the low-fat diet at any time of day (Fig. 2).

\section{Rat CRBPII gene promoter transactivation by fatty acids via $P P A R \alpha / R X R \alpha$ heterodimer}

In order to clarify the mechanism of dietary-fat induced CRBPII gene expression, we performed transient transfection assay. Rat CRBPII gene promoter activity increased in the CV-1 cells transiently expressing PPAR $\alpha$ and RXR $\alpha$ (Fig. 3(a)) in the absence of fatty acids. Furthermore, linoleic acid and arachidonic acid further induced the $\operatorname{PPAR} \alpha / \operatorname{RXR} \alpha$ heterodimer-mediated transactivity. Similar results were observed in the reporter vector which was ligated only rat CRBPII gene RE3 element (Fig. 3(b)).

\section{Discussion}

A number of studies have reported the presence of diurnal variations or circadian rhythms in intestinal digestive and absorptive capability. Investigations into the diurnal variations in disaccharidase and glucose transporters in the rodent's small intestine have revealed that these diurnal variations were closely related to food intake, but that the increase in their protein and/or mRNA levels occurred before the onset of feeding (Saito et al. 1975, 1976; Furuya et al. 1979; Castello et al. 1995; Corpe \& Burant, 1996). Although the precise mechanism leading to the diurnal variations in these enterocyte-specific proteins is unknown, several possibilities have been suggested. One is related to diurnal variation in the enterocyte cell populations. The number of absorptive cells and the villus height in rat jejunum were reported to be elevated before the start of feeding (Stevenson et al. 1979), which appeared to correlate with diurnal variations in sucrase activity (Saito et al. 1975, 1976) and glucose transporter mRNA levels (Corpe \& Burant, 1996). Furthermore, it has recently been reported that the diurnal variations in some disaccharidase and glucose transporters in the rat small intestine might be 
(a)

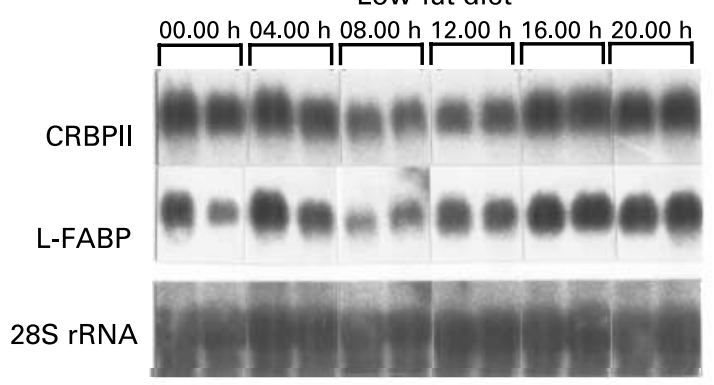

High-fat diet

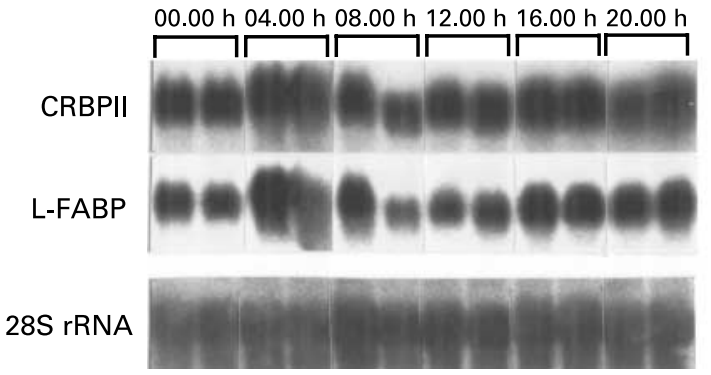

Fat-free diet

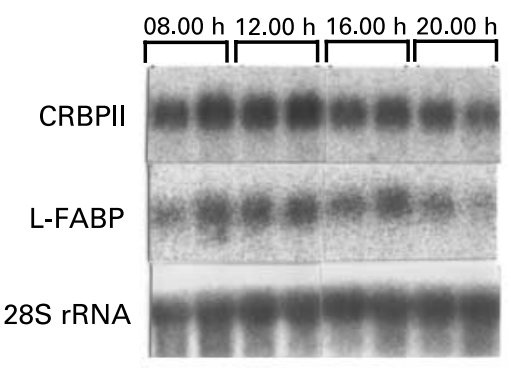

Fasting

$08.00 \mathrm{~h} 12.00 \mathrm{~h} 16.00 \mathrm{~h} 20.00 \mathrm{~h}$

CRBPII

L-FABP

28S rRNA

(b)
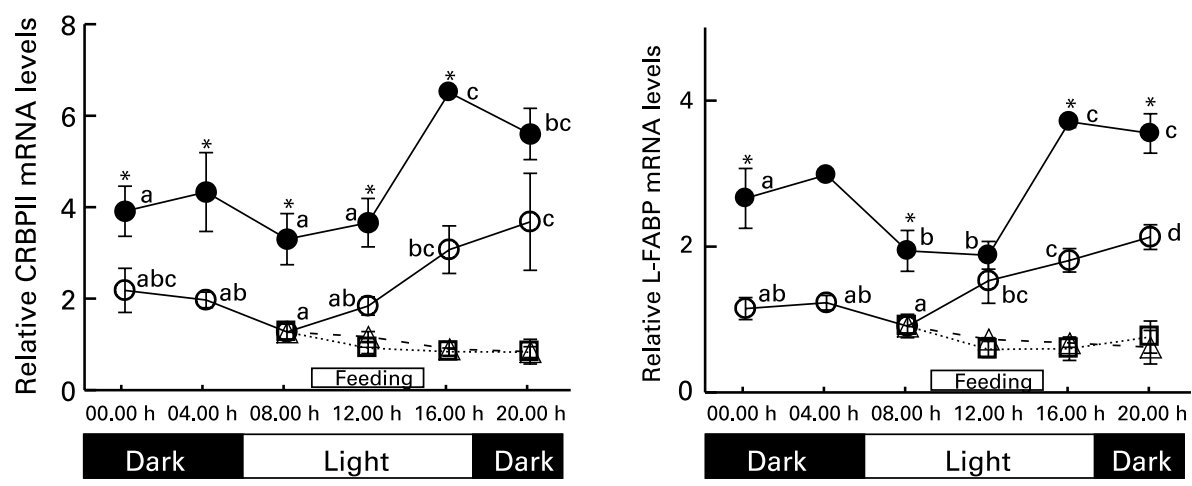

Fig. 2. Effects of dietary fat on the variations of cellular retinol-binding protein II (CRBPII) and liver fatty acid-binding protein (L-FABP) mRNA levels in rat jejunum. Rats had restricted access to either a low-fat diet or a high-fat diet during the time indicated (between $09.00 \mathrm{~h}$ and $15.00 \mathrm{~h}$ ) for $13 \mathrm{~d}$, and on the last day they were fed various diets or fasted. For further details, see pp. 885-886. The rats were killed at $4 \mathrm{~h}$ intervals. (a) Results of Northern blot analysis of the jejunal CRBPII, LFABP and 28S rRNA transcripts. Two representative blots at each time are shown for comparison. (b) Graphical representation of relative jejunal CRBPII and LFABP mRNA levels normalised for corresponding 28S rRNA levels and expressed in arbitrary units. Values represent means and their standard errors for at least

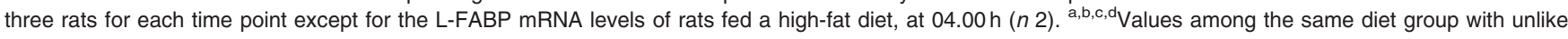
superscript letters on the same curve are significantly different at $P<0.05$ by Ryan's multiple range test. *Significant difference at $P<0.05$ compared with the

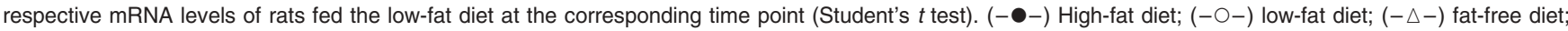
$(-\square-)$ fasting.

regulated by the nuclear transcription factor hepatocyte nuclear factor-1 (Rhoads et al. 1998).

The results in the present study indicated that both CRBPII protein and CRBPII mRNA exhibited a diet-related variation in rat jejunum. It should be noted that the pattern of diet-related variation in CRBPII content in the jejunum (Fig. 1) was distinct from that of disaccharidase activities, which were reported to start increasing prior to the feeding period (Saito et al. 1976). Since it was apparent that the significant increase in CRBPII mRNA occurred several hours after the start of the feeding period (Fig.1), we considered it possible that some component(s) in the diet might be responsible for the feeding-dependent variation at the gene expression level.
We previously demonstrated that jejunal CRBPII and L-FABP mRNA levels were increased by feeding a diet rich in long-chain triacylglycerols (Goda et al. 1994; Suruga et al. 1999; Mochizuki et al. 2001) and that the increase was triggered specifically by dietary unsaturated fatty acids derived from long-chain triacylglycerols (Suruga et al. 1995). Therefore, in this study we examined whether the diet-related variation in jejunal CRBPII and L-FABP mRNA levels would be influenced by the fat content of the diet. As we expected, the CRBPII and L-FABP mRNA levels of animals fed the high-fat diet were higher than those of rats fed the low-fat diet at any time investigated throughout the $24 \mathrm{~h}$ period (Fig. 2). In addition, mRNA levels increased after the onset of feeding in the groups of rats fed a low-fat diet or a high-fat 

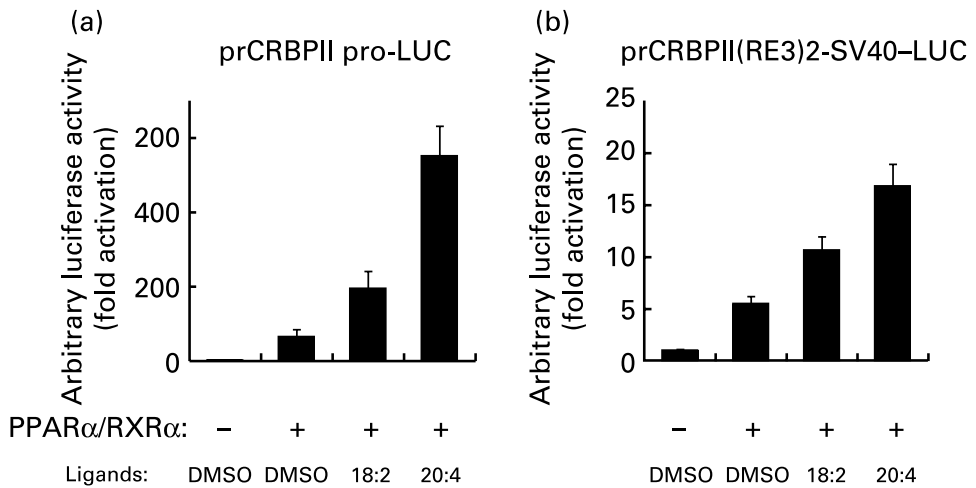

Fig. 3. Fatty acids increase the rat cellular retinol-binding protein II (CRBPII) gene promoter activity via the PPAR $\alpha /$ retinoid X receptor- $\alpha$ (RXR $\alpha$ ) heterodimer. CV-1 cells plated on ninety-six-well plate were co-transfected with pCMX mock vector $(-)$ or both pCMX-RXR $\alpha$ and pCMX-PPAR $\alpha$ expression vectors $(+)$, phRG-TK Renilla control luciferase vector and prCRBPII-pro-LUC vector (a) or prCRBPII(RE3) $)_{2}$-SV40-LUC vector (b) using TfX-10 transfection reagent. For further details, see pp. 885-886. After the transfection, cells were incubated for $48 \mathrm{~h}$ in the serum-free medium containing vehicle alone $(0.1 \%$ dimethyl sulfoxide

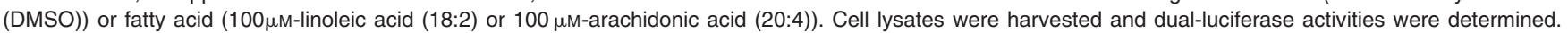
Values (means and their standard errors, $n 6$ ) were expressed as fold induction over pCMX mock vector.

diet, but not in the rats fed a fat-free diet (Fig. 2). These results suggest that dietary fat may be a dominant factor in the dietrelated variation in small intestinal CRBPII and L-FABP gene expression.

It has been reported that rat CRBPII gene expression might be transcriptionally regulated by several nuclear receptor superfamilies via nuclear receptor response elements located in the CRBPII gene 5'-flanking region (Mangelsdorf et al. 1991; Nakshatri \& Chambon, 1994; Nakshatri \& Bhat-Nakshatri, 1998). A similar nuclear receptor response element also existed in the rat L-FABP gene 5'-flanking region (Issemann et al. 1992). Among various types of nuclear receptor, PPAR and hepatocyte nuclear factor- 4 were activated by fatty acids and/or their metabolites as their ligands (Forman et al. 1997; Hertz et al. 1998). We and others also reported that the PPAR/RXR heterodimer and hepatocyte nuclear factor-4 homodimer bound to the rat CRBPII and L-FABP gene's nuclear receptor response elements (Nakshatri \& Chambon, 1994; Poirier et al. 1997; Nakshatri \& Bhat-Nakshatri, 1998; Suruga et al. 1999; Mochizuki et al. 2001). We further demonstrated in this study that unsaturated fatty acids such as linoleic acid and arachidonic acid, a major dietary fatty acid component and potent natural PPAR ligand (Forman et al. 1997), increased the promoter activity of rat CRBPII gene via the PPAR $\alpha / R X R \alpha$ heterodimer on the RE3 element located in the proximal $5^{\prime}$-flanking region of the rat CRBPII gene (Fig. 3). Schachtrup et al. (2004) also recently reported that PPAR/RXR heterodimer could transactivate the murine L-FABP nuclear receptor response element. It was therefore suggested that other PPAR/RXR heterodimer-dependent genes in the small intestine might show a similar diet-related variation induced by feeding of dietary fat.

Whereas CRBPII is the major cytosolic retinol-binding protein in the small intestine (Ong, 1984), other types of retinol-binding proteins, such as CRBP and retinol-binding protein, are abundantly expressed in the liver. We observed that hepatic retinol-binding protein and CRBP mRNA levels did not show a diet-related variation (K. Suruga, S. Takase and T. Goda, unpublished results). Although L-FABP mRNA levels in the jejunum exhibited a diet-related variation similar to that of CRBPII mRNA (Fig. 2), hepatic L-FABP mRNA levels were unchanged during the $24 \mathrm{~h}$ period (K. Suruga, S. Takase and T. Goda, unpublished results). These results suggested that the diet-related variations in the expression of the genes encoding for the binding proteins of vitamin A and fatty acids might be prominent only in the small intestine.

In conclusion, the present study demonstrated that jejunal gene expression related to vitamin A and fatty acid metabolism showed a diet-related variation that was induced by feeding dietary fat at transcriptional level but not by a diurnal rhythm of feeding.

\section{Acknowledgements}

The author thanks Dr RM Evans (Salk Institute) for the generous gift of pCMX-RXR $\alpha$ and pCMX-PPAR $\alpha$ expression vectors. This work was supported by grant-in-aid for Scientific Research from Ministry of Education, Science and Culture (0150088, 04670097), Research Fellowship of the Japan Society for the Promotion of Sciences for Young Scientists (1684), the Sasakawa Scientific Research Grant from The Japan Science Society (9-216K) and the Foundation for Health Science Research (71009).

\section{References}

Castello A, Guma A, Sevilla L, Furriols M, Testar X, Palacin M \& Zorzano A (1995) Regulation of GLUT5 gene expression in rat intestinal mucosa: regional distribution, circadian rhythm, perinatal development and effect of diabetes. Biochem J 309, 271-277.

Chomczynski P \& Sacchi N (1987) Single-step method of RNA isolation by acid guanidinium thiocyanate-phenol-chloroform extraction. Anal Biochem 162, 156-159.

Corpe CP \& Burant CF (1996) Hexose transporter expression in rat small intestine: effects of diet on diurnal variations. Am J Physiol 271, G211-G216.

Forman BM, Chen J \& Evans RM (1997) Hypolipidemic drugs, polyunsaturated fatty acids, and eicosanoids are ligands for peroxisome-proliferator-activated receptors $\alpha$ and $\delta$. Proc Natl Acad Sci USA 94, $4312-4317$.

Furuya S, Sitren HS, Zeigen S, Offord CE \& Stevenson NR (1979) Alterations in the circadian rhythmicity of rat small intestinal functions. J Nutr 109, 1962-1973.

Goda T \& Koldovsky O (1988) Dietary regulation of small intestinal disaccharidases. World Rev Nutr Diet 57, 275-329. 
Goda T \& Takase S (1989) Purification, properties, and developmental changes of cellular retinol-binding protein, type II, in chicken intestine. J Nutr Sci Vitaminol 35, 545-557.

Goda T, Yasutake H \& Takase S (1994) Dietary fat regulates cellular retinol-binding protein II gene expression in rat jejunum. Biochim Biophys Acta 1200, 34-40.

Hertz R, Magenheim J, Berman J \& Bar-Tana J (1998) Fatty acyl-CoA thioesters are ligands of hepatic nuclear factor-4 $\alpha$. Nature 392, 512-516.

Issemann I, Prince R, Tugwood J \& Green S (1992) A role for fatty acids and liver fatty acid binding protein in peroxisome proliferation. Biochem Soc Trans 20, 824-827.

Kakkad B \& Ong DE (1988) Reduction of retinaldehyde bound to cellular-retinol-binding protein (type II) by microsomes from rat small intestine. J Biol Chem 263, 12916-12919.

Kishi K, Tanaka T, Igawa M, Takase S \& Goda T (1999) Sucrase-isomaltase and hexose transporter gene expression are coordinately enhanced by dietary fructose in rat jejunum. $J$ Nutr 129, 935-936.

Levin MS, Li E, Ong DE \& Gordon JI (1987) Comparison of the tissuespecific expression and developmental regulation of two closely linked rodent genes encoding cytosolic retinol-binding proteins. J Biol Chem 262, 7118-7124.

Mangelsdorf DJ, Umesono K, Kliewer SA, Borgmeyer U, Ong ES \& Evans RM (1991) A direct repeat in the cellular retinol-binding protein type II gene confers differential regulation by RXR and RAR. Cell 56, $555-561$.

Mochizuki K, Suruga K, Kitagawa M, Takase S \& Goda T (2001) Modulation of the expression of peroxisome proliferator-activated receptordependent genes through disproportional expression of two subtypes in the small intestine. Arch Biochem Biophys 389, 41-48.

Nakshatri H \& Bhat-Nakshatri P (1998) Multiple parameters determine the specificity of transcriptional response by nuclear receptors HNF4, ARP-1, PPAR, RAR and RXR through common response elements. Nucleic Acid Res 26, 2491-2499.

Nakshatri H \& Chambon P (1994) The directly repeated RG(G/T)TCA motifs of the rat and mouse cellular retinol-binding protein II genes are promiscuous binding sites for RAR, RXR, HNF-4, and ARP-1 homo-and heterodimers. J Biol Chem 269, 890-902.

Ong DE (1984) A novel retinol-binding protein. Purification and partial characterization. J Biol. Chem 259, 1476-1482.

Ong DE, Kakkad B \& MacDonald PN (1987) Acyl-CoA-independent esterification of retinol bound to cellular retinol-binding protein (type II) by microsome from rat intestine. J Biol Chem $\mathbf{2 6 2}$, 2729-2736.

Ong DE \& Page DI (1987) Cellular retinol-binding protein (type II) is present in human small intestine. J Lipid Res 28, 739-745.

Poirier H, Braissant O, Niot I, Wahli W \& Besnard P (1997) 9-cis-retinoic acid enhances fatty acid-induced expression of the liver fatty acid-binding protein gene. FEBS Lett 412, 480-484.

Rhoads DB, Rosenbaum DH, Unsal H, Isselbacher KJ \& Levitsky L (1998) Circadian periodicity of intestinal $\mathrm{Na}^{+} /$glucose cotransporter 1 mRNA levels is transcriptionally regulated. J Biol Chem 273, 9510-9516.

Saito M, Murakami E, Nishida T, Fujisawa Y \& Suda M (1975) Circadian rhythms in digestive enzymes in the small intestine of rats. I. Patterns of the rhythms in various regions of the small intestine. J Biochem $\mathbf{7 8}$, 475-480.

Saito M, Murakami E \& Suda M (1976) Circadian rhythms in disaccharidases of rat small intestine and its relation to food intake. Biochim Biophys Acta 421, 177-179.

Schachtrup C, Emmler T, Bleck B, Sandqvist A \& Spener F (2004) Functional analysis of peroxisome-proliferator-responsive element motifs in genes of fatty acid-binding proteins. Biochem J 382, 239-245.

Stevenson NR, Day SE \& Sitren H (1979) Circadian rhythmicity in rat intestinal villus length and cell number. Int J Chronobiol 6, 1-12.

Suruga K, Goda T, Igarashi M, Kato S, Masushige S \& Takase S (1997) Cloning of chick cellular retinol-binding protein, type II and comparison to that of some mammals: expression of the gene at different developmental stages, and possible involvement of RXRs and PPAR. Comp Biochem Physiol 118A, 859-869.

Suruga K, Mochizuki K, Goda T, Horie N, Takeishi K \& Takase S (1999) Transcriptional regulation of cellular retinol-binding protein, type II gene expression in small intestine by dietary fat. Arch Biochem Biophys 362, 159-166.

Suruga K, Suzuki R, Goda T \& Takase S (1995) Unsaturated fatty acids regulate gene expression of cellular retinol-binding protein, type II in rat jejunum. J Nutr 125, 2039-2044.

Takase S, Goda T \& Shinohara H (1993) Adaptive changes of intestinal cellular retinol-binding protein, type two following jejunum-bypass operation in the rat. Biochim Biophys Acta 1156, 223-231.

Takase S, Tanaka K, Suruga K \& Goda T (1998) Dietary fatty acids are key determinants of cellular retinol-binding protein, type II gene expression in rat jejunum. Am J Physiol 274, G626-G632. 